\title{
Measuring Amil Happiness Using Psychological Approach: Evidence from Yogyakarta, Indonesia
}

\author{
Zaki Abdullah, Duddy Roesmara Donna \\ Graduate School, Universitas Gadjah Mada
}

\section{Dinda Aisyah Najmi}

Faculty of Economics and Management, IPB University

\begin{abstract}
The implementation of Good Amil Governance as one of the important aspects of a standard of international zakat management, which is stated in Zakat Core Principles, requires an approach that is more than just amil competence and qualification aspects. The psychological perspective of amil also needs to be considered to obtain and maintain the best human resources. As a profession that is oriented towards social benefits, an amil has different working rhythm and consequences. This research aims to measure level of amil's happiness in the workplace and further study its impact on amil productivity. The result shows that amil is a satisfying job. Further, the most blissful factor for amil is work motivation, while the most unhappy factor for amil is the career path, which seems to be less promising. In addition, the happiness level of amil has a positive relationship with his or her productivity level. Therefore, psychology condition of an amil should be considered in order to increase the performance of zakat institutions.
\end{abstract}

Keywords: Amil Zakat, Good Amil Governance, Happiness, Productivity, Psychology JEL Classification: D23, D91

\section{INTRODUCTION}

Poverty and the gap in economic welfare are the problems of developing countries. Therefore, the poverty alleviation and gap of economic decrease indicators are included in Sustainable Development Goals (SDGs) of The United Nations, as a development goal for human. Zakat becomes one of the right tools to reduce poverty and the gap of economic welfare (Beik, 2009). A study by Firdaus et al. (2012) found that the potential of zakat in Indonesia reached Rp.16.2billion or $3.4 \%$ of Indonesia's GDP in 2010. Further, in 2019, research done by BAZNAS Center for Strategic Studies shows that potential of zakat fund is at Rp.21.3billion. This zakat fund can serve as a tool to decrease poverty and the gap in the economy.

According to Statistik Zakat Nasional (2017), the current collection of zakat remains at Rp. 454million or 2.8 percent from the measured potential. There are still many tasks to be done by zakat institutions in digging the potential of zakat. As an effort to optimize the existing potential, zakat management should be well driven by competent and credible institutions. Beik et al. (2016) provide the reference of Zakat Core Principles that are fundamental principles of zakat management as an effort by the zakat institutions to implement the ideal management zakat system.

One of the critical principles of zakat institutions is Good Amil 
Governance. This is because amil is the motor of the system in zakat institutions covering administration, collection, and distribution of zakat. This matter strengthened by Rusydiana \& Firmansyah (2017) in their research that put Good Amil Governance as the most priority aspect of Supervision. This shows that this aspect is one of the considered principles in supporting the optimization of existing zakat potentials.

The implementation of Good Amil Governance can be conducted by implementing the following aspects; transparency, accountability, responsibility, justice, and local wisdom (Chotib et al., 2018). Therefore, it is necessary for an amil to be competent and professional in accordance with the required field.

However, in addition to the competency and professional factors of an amil, the psychological well-being in the implementation of Good Amil Governance also needs to be a concern. In this regard, well-being has a broad meaning. Thus, the measurement of well-being using arranged indicators that not only to describe the condition of material prosperity but also lead to the condition of subjective welfare or happiness (BPS, 2017).

As elaborated in the above text, this paper aims to measure the degree of amil's happiness using a psychological approach method.

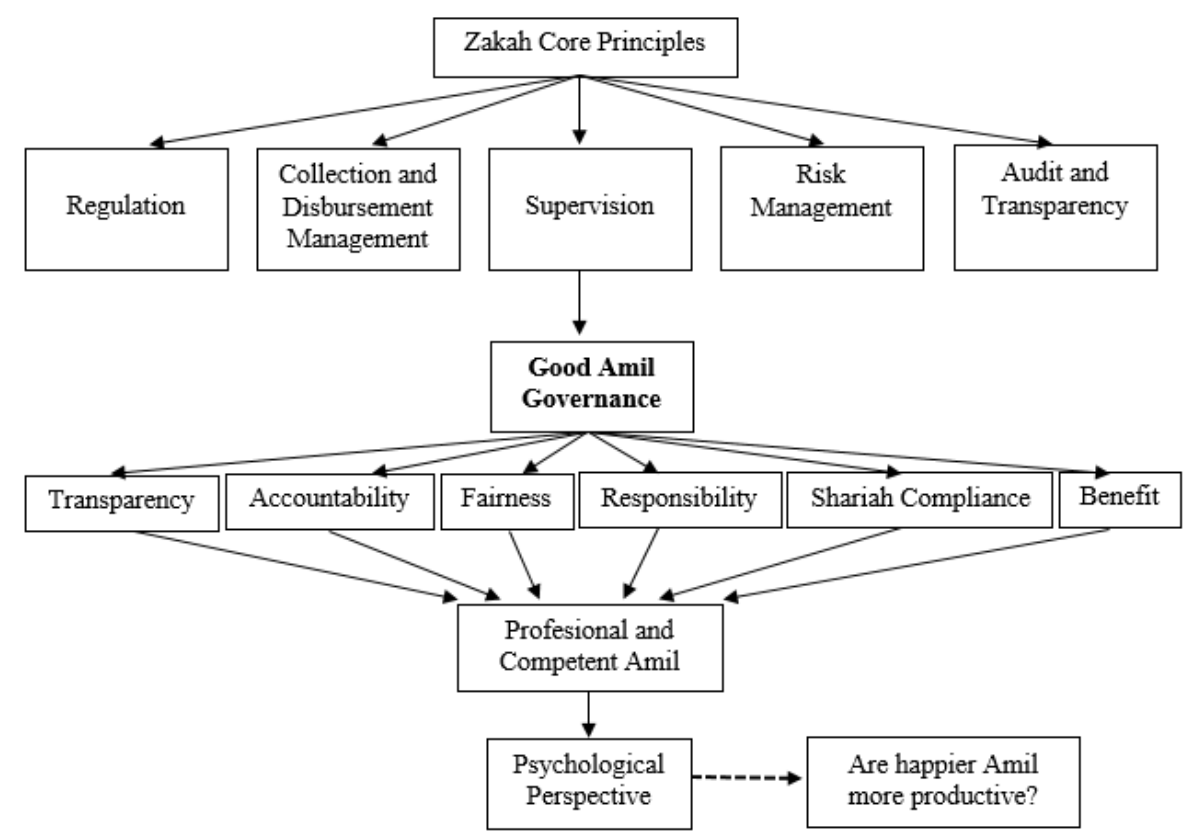

Figure 1. Framework of Thinking

Source: Authors' own.

\section{LITERATURE REVIEW}

In research conducted by Sharifzadeh \& Almaraz (2014), it was found that happy workers tend to be more productive than those who are less happy. Workers also do not need to worry and can focus on their work because all of their needs are satisfied. That also goes to amils. In this regard, an amil who works happily will be more loyal to the zakat institution where he or she works.

Cadmus (2012) in his study found that among the factors that 
influence the happiness of a worker, in special relation to psychological well-being, is a relevant workload, work time and balanced life, decent salary, a positive environment, and a clear career path. Although happiness in workplace cannot be achieved continuously, these factors need to be considered by human resources (HR) managers. The target and productivity of the institution that will be achieved need to be determined realistically and wisely by looking at the aspects of the resources they have.

Work motivation has a positive impact on the commitment to an organization (Mangkunegara \& Octorend, 2015). Work motivation also has a positive effect on employee happiness. Workers who are increasingly motivated and committed will work better and be satisfied (Sohail et al, 2014). As a non-profit institution, zakat institution has different characteristics compared to that of profit-oriented ones, including in managing their human resources. This circumstance is because there is no production or sales process in zakat institutions, but making the collection of zakat funds as a factor of production, then channeling the fund to the mustahik in order to equalize social economics condition in the society. These different goals make the work motivation of employees at the zakat institution different.

As the above, it can be concluded that the happiness of an amil in work is needed because the implementation of Good Amil Governance as one of the Zakat Core Principles cannot be carried out without the support of amil psychological factors. Disorders of psychological factors will harm amil's performance and his or her professionalism. For example, the factors of financial inadequacy, unclear career paths, less suitable work environment, heavy workload, and passion discrepancy, should bring down an amil's performance.

\section{Objectives}

The psychological aspect of an amil is an essential variable in zakat institution. That is because the condition of an amil as a motor of zakat institution will determine the productivity and achievement of the institution. This research tries to look at the role and management of amil from a different perspective, which is related to the psychology of amil in managing zakat funds.

Psychological well-being can be measured through the happiness of amil in the workplace. Happiness can be measured through several latent variables. Thereby, there are 2 (two) objectives in this study which are; measuring happiness of amil zakat institutions in Yogyakarta, and investigating its impact on amil productivity.

Measuring amil happiness in Yogyakarta is interesting due to Yogyakarta is the happiest province in Java Island (BPS, 2017). Java Island is the most strategic island in Indonesia because it is the center of economic and business activities in the country. It also contributes the most to Indonesia's GDP. Meanwhile, Yogyakarta is one of the exclusive provinces in Indonesia and the happiest province among other special regions such as DKI Jakarta, Aceh, and Papua based on Indonesia Happiness Index.

\section{METHODOLOGY}

\section{Work Happiness Factors of Amil}

Happiness can be measured through several factors to describe amil 
satisfaction as worker in general. The happier person will make him or her more productive at work (Sgroi, 2015). Based on the principle of Good Amil Governance in the Zakat Core Principles, an amil does not only have an orientation to work, but also charity under the zakat institution as a social organization at the same time. These factors can also illustrate the psychological side of an amil profession. The proxies of happiness of amil can be described by the following factors:

Table 1. Determinants of Happiness at Work

\begin{tabular}{|c|c|c|}
\hline No & $\begin{array}{c}\text { Determinants of } \\
\text { Worker } \\
\text { Happiness }\end{array}$ & Reference \\
\hline 1 & Workload & $\begin{array}{l}\text { Cadmus (2012), } \\
\text { Shah et al (2011) }\end{array}$ \\
\hline 2 & Career Path & $\begin{array}{l}\text { Cadmus (2012), } \\
\text { SEEK Asia (2017) }\end{array}$ \\
\hline 3 & $\begin{array}{l}\text { Financial } \\
\text { Welfare/Salary }\end{array}$ & $\begin{array}{l}\text { Cadmus (2012), } \\
\text { SEEK Asia } \\
\text { (2017), Wulandari } \\
\text { \& Widyastuti } \\
\text { (2014) }\end{array}$ \\
\hline 4 & Work Motivation & $\begin{array}{l}\text { Sohail et al } \\
\text { (2014), } \\
\text { Mangkunegara \& } \\
\text { Octorend (2015) } \\
\end{array}$ \\
\hline 5 & $\begin{array}{l}\text { Work } \\
\text { Environment }\end{array}$ & $\begin{array}{l}\text { Cadmus (2012), } \\
\text { SEEK Asia } \\
\text { (2017), Wulandari } \\
\text { \& Widyastuti } \\
\text { (2014), Fernández } \\
\text { et al (2017) }\end{array}$ \\
\hline 6 & Working Time & $\begin{array}{l}\text { Cadmus (2012), } \\
\text { SEEK Asia } \\
\text { (2017), Fernández } \\
\text { et al (2017) }\end{array}$ \\
\hline 7 & Passion & $\begin{array}{l}\text { Spehar et al } \\
\text { (2016), Purba \& } \\
\text { Ananta (2018) }\end{array}$ \\
\hline
\end{tabular}

Source: Prepared by Authors.

Types and Data Sources
The data used in this study is the primary data. It is obtained directly through field surveys. The data retrieval method is conducted by filling out the administered questionnaires that have been made and processed by the authors. The data in the questionnaire is ordinal. The data was obtained from 46 respondents who were amils of zakat institutions in Yogyakarta. The selection of respondents was done with a purposive sampling method, which determines the respondent based on the provisions made by the authors.

The amils involved in this study were from 3 (three) official zakat institutions, including BAZNAS Yogyakarta City, BAZNAS Yogyakarta Province, and Dompet Dhuafa (DD) Yogyakarta.

\section{Analysis Method}

The data obtained from the primary source was processed by a validity test to determine the validity of question as a proxy which illustrates the happiness of amil. After that, the reliability test is conducted to determine the level of questionnaire consistency. Furthermore, descriptive analysis is conducted to measure the happiness of amils in their working environment. The measuring scale is at the range from 1 to 5 where number 3 is neutral. The bigger the score describes the happier is an amil. Further, Pearson Correlation Analysis is used to determine the relationship between the happiness level of amil to the level of productivity at work.

\section{RESULTS AND DISCUSSION}

\section{Validity and Reliability Test}

After the completion of the questionnaires, the validity test was conducted. There were 25 from 35 questions that have fulfilled the prerequisites to be valid. The 25 
questions have r-count $>$ r-table based on the significant test at a level of 5 percent. While the other ten questions were invalid because the error level of more than 0,05 percent.

Table 2. Result of Validation Test

\begin{tabular}{|l|l|c|c|c|}
\hline Item & Indicator & $\begin{array}{c}\text { Correlation } \\
\text { Coeff. }\end{array}$ & r-table & Conclusion \\
\hline X1.1 & $\begin{array}{l}\text { Work } \\
\text { Motivation }\end{array}$ & 0,746 & 0,444 & Valid \\
\hline X1.2 & $\begin{array}{l}\text { Work } \\
\text { Motivation }\end{array}$ & 0,492 & 0,444 & Valid \\
\hline X1.3 & $\begin{array}{l}\text { Work } \\
\text { Motivation }\end{array}$ & 0,493 & 0,444 & Valid \\
\hline X1.4 & $\begin{array}{l}\text { Work } \\
\text { Motivation }\end{array}$ & 0,714 & 0,444 & Valid \\
\hline X2.1 & $\begin{array}{l}\text { Working } \\
\text { Time }\end{array}$ & 0,673 & 0,444 & Valid \\
\hline X2.2 & $\begin{array}{l}\text { Working } \\
\text { Time }\end{array}$ & 0,490 & 0,444 & Valid \\
\hline X2.3 & $\begin{array}{l}\text { Working } \\
\text { Time }\end{array}$ & 0,528 & 0,444 & Valid \\
\hline X3.1 & $\begin{array}{l}\text { Work } \\
\text { Environment }\end{array}$ & 0,676 & 0,444 & Valid \\
\hline X3.2 & $\begin{array}{l}\text { Work } \\
\text { Environment }\end{array}$ & 0,577 & 0,444 & Valid \\
\hline X3.3 & $\begin{array}{l}\text { Work } \\
\text { Environment }\end{array}$ & 0,578 & 0,444 & Valid \\
\hline X4.1 & Workload & 0,763 & 0,444 & Valid \\
\hline X4.2 & Workload & 0,521 & 0,444 & Valid \\
\hline X4.3 & Workload & 0,809 & 0,444 & Valid \\
\hline X5.1 & Career Path & 0,728 & 0,444 & Valid \\
\hline X5.2 & Career Path & 0,696 & 0,444 & Valid \\
\hline X5.3 & Career Path & 0,562 & 0,444 & Valid \\
\hline X5.4 & Career Path & 0,602 & 0,444 & Valid \\
\hline X6.1 & Passionate & 0,513 & 0,444 & Valid \\
\hline X6.2 & Passionate & 0,694 & 0,444 & Valid \\
\hline X6.3 & Passionate & 0,723 & 0,444 & Valid \\
\hline X7.4 & Passionate & 0,796 & 0,444 & Valid \\
\hline X7.1 & Salary & 0,717 & 0,444 & Valid \\
\hline X7.2 & Salary & 0,684 & 0,444 & Valid \\
\hline X7.3 & Salary & 0,590 & 0,444 & Valid \\
\hline X7.4 & Salary & 0,665 & 0,444 & Valid \\
\hline
\end{tabular}

Source: computed by Authors (2019).

Following the validity test above, the authors performed the reliability test to all variables considered valid. The test involved the consistency test of the questionnaire. Rule of thumb of alpha value or composite reliability should be more than 0.7 although 0.6 is still acceptable (Hair et al. dalam Putri \& Gunawan, 2014).

The result of the reliability test of the 25 valid questions shows that the questionnaire is highly reliable as can be seen in Table 3.

Table 3. Result of Reliability Test

\begin{tabular}{|c|c|}
\hline $\begin{array}{c}\text { Cronbach's } \\
\text { Alpha }\end{array}$ & $\begin{array}{c}\text { Number of } \\
\text { Statement }\end{array}$ \\
\hline 0.945 & 25 \\
\hline
\end{tabular}

Source: computed by Authors (2019).

Cronbach's Alpha 0.945 value shows that the 25 questions on the employed questionnaire have a relatively high degree of reliability. After validity and reliability tests, the analysis of the respondents' answers is further conducted.

\section{Analysis of Amil's Happiness at Work}

The result of a descriptive analysis obtained from the average of respondents has shown several findings. The career path was found to be the least unhappy factor for the sampled amils with 3.78 (the lowest score). The reason for being so, perhaps, the majority of amils in zakat institutions in Yogyakarta are employed based on contract scheme. This type of employment represents that amil profession is not a permanent job.

Further, regarding the permanent amil in the sampled institutions, as authors have found, only totaling 5 to 10 amils are employed permanently. Perhaps, such employment has led to the quick change of human resources, which to some degree, could create a risk to the zakat institution itself. It is important to be noted that the quality of an employee will be improved with a clear career path (Dewi \& Utama, 2016). However, from 
the current findings, the impermanent occupations factor, the career path offered by the zakat institutions, are found to be unclear and less promising.

Although zakat institution is a non-profit institution, the management must be professionally conducted. Therefore, amil as a zakat fund manager needs to have adequate and relevant qualifications and loyalty to the institution. If amil's turnover happens in a short time because the offered career path is less-promising, that regard will weaken the institution. Career path in zakat institution must be made different from those in the conventional company or civil servant.

Following the factor of career path, the workload was further found with a score of 4 . It seems that workload in the sampled zakat institutions is less enjoyed by the respective amils. Perhaps, the workload given by the zakat institution does not meet the amil standard of qualification. The workload can encourage employee productivity, but excessive workloads will result in an adverse impact on the form of physical or mental fatigue (Irawati \& Carolina, 2017).

Further, the next factor that contributes to the happiness of amil is passion based on the relationship between the expectation and abilities of amil and the current field of work. The result of this factor has a score of 4.02, which can be said to be quite good. This score, perhaps, means that the sampled amils's passions are in line with their tasks. The jobs in administration, finance, fundraising, management or services, are expected by the sample. Nevertheless, there is an important note in one of the statements as a proxy for the passion of work which is related to the desired job. On average, the respondents answered that they were not sure that amil was the profession they wanted or aspired.

Another indicator that measures the happiness of amil is salary. The results show that the salary of an amil has a score of 4.03. This result represents that amils in zakat institution is quite happy with the salary they earn, notably in the context of amils who work in the sampled institutions. Based on the results of interviews, the average salaries of the amil certainly not as big as in companies or other profit institutions. However, the salary they earn is in accordance the work they have done. The amount of their income is above the regional minimum wage. The amount can fulfill daily needs, which is fair and reasonable.

In addition to the above, the environment at work was also utilized to measure the happiness of amil. The environment in zakat institutions in Yogyakarta was found to be fairly good with a score of 4.30. This score is much better than the four previous factors. It means that the amils in zakat institutions in Yogyakarta are happy with the conditions of the existing environment.

A pleasant work environment supports employees to work productively. The colleagues in workplace also support each other and do not overturn each other's work. The highest quality standards also must be applied to keep the work environment productive and professional. Zakat institutions in Yogyakarta have implemented that regard. This condition was reflected in the sampled amil happiness score as above mentioned.

The other two factors that were found to be good for the happiness of amil in zakat institutions in Yogyakarta are the factors of working time and motivation. The office hours are not too tight and ideal (8 hours of work). On that, an amil is given proportional time for 
vacation and leave. The policy about the standard of working hours and overtime is following the Law No. 13 of 2003 about Manpower. Furthermore, the amil can enjoy working moments, and daily work can be completed on time. The happiness score for working time factor is 4.45 .

The last factor is work motivation. It contributes to the highest score as a happiness factor of amil zakat in Yogyakarta with a score of 4.46 . Perhaps, this is because the motivation as an amil aims at helping people in need. Amil job is a noble profession as Allah mentioned in the Qur'an Chapter 9 (Surah At-Taubah) verse 60. The score of happiness based on this high working motivation shows that the amils are the ones who have a high social spirit and a good level of spirituality. Based on the work motivation they had, the amils feel happy even though they do not expect their current job.

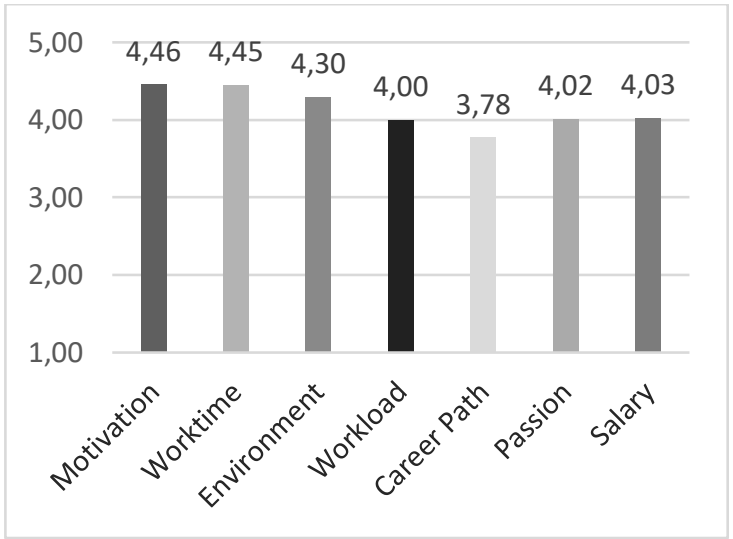

Source: computed by Authors (2019).

Figure 2. Level of Amil Happiness by Determinants

Based on the seven factors as a mean of measuring the happiness of amil in Yogyakarta above, then an average score of 4.15 is obtained. This score shows that the profession of amil is a satisfying job and this means that the sampled amils are happy.
Happiness covers not only the material aspect but also non-material such as the needs of spirituality, social contacts, and suitability in the field of work. In this regard, the authors have records that zakat institution can do to increase the happiness of amil, which can improve career and development path of its amil.

\section{The Relationship between Work Happiness and Productivity of Amil}

After knowing the level of work happiness of amil, it is important to investigate the relationship between work happiness to the productivity of amil in order to better understand this subject matter. In this study, the test is done following Sharifzadeh \& Almaraz (2014) dan Sgroi (2015), who found that that happy workers tend to be more productive at work.

The result of the descriptive analysis from the questionnaires indicated that each happiness factor has different contributions to the level of amil productivity. The level of happiness from work motivation has the most significant contribution to the sampled amils productivity with a score of 4.50 . Perhaps, this is because the work motivation factor encourages someone to work better while they enjoy the job. The happiness of amil as a result of the work motivation factor has a high score. Therefore, it is natural when the work motivation occupies the highest position in influencing productivity.

Furthermore, the factor which has the most significant contribution to amil productivity after work motivation is working time and working environment with the same score of 4.40 . That was then followed by a passion for work with score of 4.30 , salary with 4.20 and workload with a score of 4,10 . While the factor that affects productivity with 
the lowest score is the career path with 3.75 .

As the level of happiness, the contribution of the career path in the zakat institutions makes amil feel unhappy, which may result in reduced productivity. Overall, the sampled amils agreed that the happiness factor is one of the factors that affect their productivity. That was indicated by the average score of 4.22, which states that each happiness factor has an impact on their work productivity.

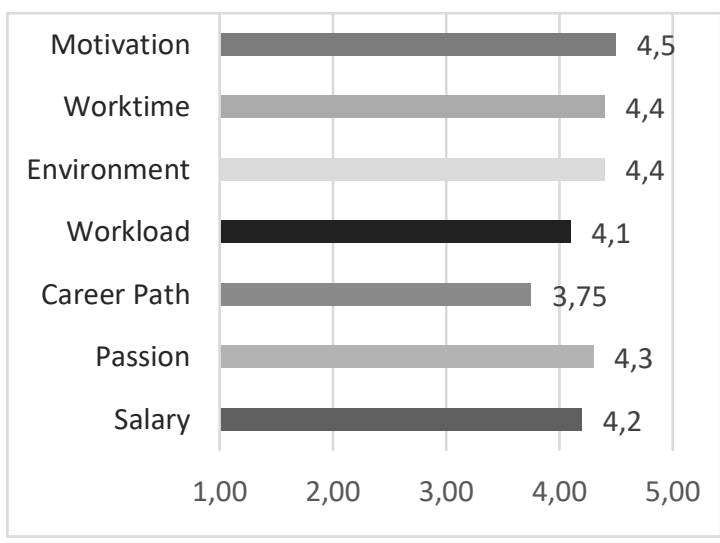

Source: computed by Authors (2019).

Figure 3. The Amount of Each Factor Contribution to Amil Productivity

Further, this study has carried out a correlation analysis to find out the relationship between happiness and productivity level of amil. Table 4 shows the findings.

Table 4. Correlation Analysis between Happiness and Productivity of Amil

\begin{tabular}{|l|c|}
\hline \multicolumn{1}{|c|}{ Correlation Value } & \multicolumn{1}{c|}{$\begin{array}{c}\text { Productivity } \\
\text { Level of Amil }\end{array}$} \\
\hline $\begin{array}{l}\text { Happiness Level of } \\
\text { Amil }\end{array}$ & 0,899 \\
\hline $\begin{array}{l}\text { Number of Variable } \\
\text { (N) }\end{array}$ & 7 \\
\hline
\end{tabular}

Source: computed by Authors (2019).
The result of the Pearson correlation was 0.899 as can be seen in Table 4. These results indicate that there is a strong relationship between happiness and productivity level of amil. Therefore, even though amil is a satisfying profession, the determinants of happiness of the amil need to be continuously improved in order to increase the productivity of amil, especially in improving career paths and providing workload.

\section{CONCLUSION}

The happiness of amil zakat in Yogyakarta has been investigated in this study. The most blissful factor for amil is work motivation. The work motivation is the perception that amil is a noble profession in Islam who aims to help people in need through zakat funds. It can be concluded that the majority of amil had high spirituality and social sensitivity.

Adversely, the most unhappy factor is a career path that seems to be unclear and less promising. This factor could demotivate amil at work and reduce loyalty towards the institution. In order to keep and maintain the good amil governance, it is necessary to have a bright and promising career path map that including material plans such as financial and the position, and nonmaterial advantages such as the scope of social contributions and flexibility time to work.

In addition, the level of work happiness of amil also was covered in this paper. It has a positive relationship with the level of work productivity. The happier an amil, the more productive at work he or she will be. Therefore, the psychological conditions of an amil must be concerned and maintained in order to improve the performance of zakat 
institutions, especially for the implementation of Good Amil Governance in terms of human resources.

Finally, future research may study on similar field, which can be conducted in other regions and countries to support the evidence from the current findings.

\section{REFERENCES}

Badan Amil Zakat Nasional. 2018. Statistik Zakat Nasional 2017. Juni. BAZNAS Republik Indonesia. Jakarta.

Badan Amil Zakat Nasional. 2019. Indikator Pemetaan Potensi Zakat. Juli. BAZNAS Republik Indonesia. Jakarta.

Badan Pusat Statistik. 2017. Indeks Kebahagiaan 2017. Desember. BPS Republik Indonesia. Jakarta.

Beik, I.S. 2009. "Analisis Peran Zakat dalam Mengurangi Kemiskinan: Studi Kasus Dompet Dhuafa Republika". Jurnal Pemikiran dan Gagasan 2(1): 1-11.

Beik, I.S. 2014. "Toward an Establishment of an Efficient and Sound Zakat System: Proposed Core Principles for Effective Zakat Supervision". Disajikan dalam Working Group of Zakat Core Principles 2014.

Cadmus, F. 2012. Happiness at Work: Rules for Employee Satisfaction and Engagement. Dalam Trends. Editor Philip C. Berwick, New York: William S. Hein \& Co., Inc.

Chotib, M., Yuswadi, H., Toha A. dan Wahyudi, E. "Implementation of Good Amil Governance At Amil Zakat Institution". International Journal of Humanities and Social Science Invention 7(1): 93-100.
Dewi, N.L.P.A.A. dan Utama, I.W.M. 2016. "Pengaruh Pengembangan Karir terhadap Kinerja Karyawan melalui Mediasi Motivasi Kerja pada Karya Mas Art Gallery". EJurnal Manajemen Unud 5(9): 5494-5523.

Fernández, J.L.F., Gamez, M.A.F., Aragón, N.D.Q. dan Gil, A.C. "Happiness at Work, Business Behaviour, and Worker Perceptions: A Case Study. Ramon Llull Journal of Applied Ethics (8): 33-64.

Firdaus, M., Beik, I.S. dan Irawan T. "Economic Estimation and Determinations of Zakat Potential in Indonesia". IRTI Working Paper Series. Islamic Development Bank. 9 Oktober. Jeddah.

Irawati, R. dan Carollina, D.A. 2017. "Analisis Pengaruh Beban Kerja terhadap Kinerja Karyawan Operator pada PT Giken Precision Indonesia". Inovbiz: Jurnal Inovasi dan Bisnis 5(1): 51-58.

Mangkunegara, A.P. dan Octorend, T.R. 2015. "Effect of Work Discipline, Work Motivation and Job Satisfaction on Employee Organizational Commitment in the Company (Case Study in PT. Dada Indonesia)". Universal Journal of Management 3(8): 318-328.

Pemerintah Indonesia. 2003. Undangundang No. 13 Tahun 2003 tentang Ketenagakerjaan. Lembaran Negara Republik Indonesia Tahun 2003, No. 39. Jakarta: Sekretariat Negara.

Purba, S.D. dan Ananta, A.N.D. 2018. "The Effects of Work Passion, Work Engagement and Job Satisfaction on Turn Over Intention of The Millennial Generation". Jurnal Manajemen Dan Pemasaran Jasa 11(2): 263274. 
Putri, A.A. dan Gunawan, W. 2014. "Uji Validitas dan Reliabilitas Life Value Inventory". Jurnal NOETIC Psychology 4(2): 181-196.

Rusydiana, A.S. dan Firmansyah I. 2017. "Prioritizing Zakat Core Principles (ZCP) Criteria". Esensi: Jurnal Bisnis Dan Manajemen 7(2): 277302.

Seek Asia. 2017. Employee Job Happiness Index 2017. Desember. Seek Asia Signature Market Research. Hongkong.

Sgroi, D. 2015. "Happiness and Productivity: Understanding the Happy-Productive Worker". SMFCAGE Global Perspective Series. October. UK.

Shah, S.S.H., Jaffari, A.R., Aziz, J., Ejaz, W., Ul-Haq, I. dan Raza, S.R. 2011. "Workload and Performance of Employees". Interdisciplinary Journal of Contemporary Research in Business 3(5): 256267.

Sharifzadeh, M. dan Almaraz, J. 2014. "Happiness and Productivity in the Workplace". American Journal of Management 14(4): 19-26.

Sohail, A., Safdar, R., Saleem, S., Ansar, S. dan M. Azeem. 2014. "Effect of Work Motivation and Organizational Commitment on Job Satisfaction: (A Case of Education Industry in Pakistan)". Global Journal of Management and Business Research: A 14(6): 41-46.

Spehar, I., Forest, J., Stenseng, F. 2016. "Passion for Work, Job Satisfaction, and the Mediating Role of Belongingness". Scandinavian Journal of Organizational Psychology 8(1): 17-26.

Wulandari, S. dan Widyastuti, A. 2014. "Faktor - Faktor Kebahagiaan Di
Tempat Kerja". Jurnal Psikologi 10(1): 49-60.

Zaki Abdullah

Graduate School of

Universitas Gadjah Mada

zaki.abdullah@mail.ugm.ac.id

Dinda Aisyah Najmi

Faculty of Economics and Management IPB University

dindaaisy@apps.ipb.ac.id

Duddy Roesmara Donna

Graduate School of

Universitas Gadjah Mada

duddy@ugm.ac.id 